\title{
PENGARUH EM4 (EFFECTIVE MICROORGANISME) TERHADAP PRODUKSI BIOGAS MENGGUNAKAN BAHAN BAKU KOTORAN SAPI
}

\author{
Dwi Irawan ${ }^{1)}$, Eko Suwanto ${ }^{2)}$ \\ Program Studi Teknik Mesin, Fakultas Teknik, Universitas Muhammadiyah Metro ${ }^{1.2)}$ \\ Jl. Ki Hajar Dewantara 15 A Metro, Lampung. \\ dwi irawan12@yahoo.co.id ${ }^{1}$.
}

\begin{abstract}
Abstrak
Biogas adalah gas yang dihasilkan dari proses penguraian bahan-bahan organik oleh mikroorganisme pada kondisi langka oksigen (anaerob). Komponen biogas: $\pm 60 \% \mathrm{CH} 4$ (metana), $\pm 38 \% \mathrm{CO} 2$ (karbondioksida), $\pm 2 \% \mathrm{~N} 2, \mathrm{O} 2, \mathrm{H} 2$, dan H2S. Bahan Biogas dalam penelitian ini berasal dari kotoran sapi. Kotoran sapi merupakan substrat yang dianggap paling cocok sebagai sumber pembuat gas bio, karena substrat tersebut telah mengandung bakteri penghasil gas metan yang terdapat dalam perut hewan ruminansia. Selain kotoran sapi dijadikan biogas juga dapat mengurangi pencemaran lingkungan di samping menghasilkan sumber energi yang lebih ramah lingkungan. Penelitian ini bertujuan mengetahui pengaruh dalam penambahan EM4 yaitu terhadap produksi biogas yang dihasilkan. Penelitian dilakukan Di Laboratorium Kampus II Universitas Muhammdiyah Metro. Metode yang digunakan dengan perbandingan kotoran sapi dan air, 1 : 1 dengan penambahan EM4 (Effective microorganisme), $8 \%, 9 \%$, dan $10 \%$ dengan volume digester 90 liter. Hasil penelitian ini dengan penambahan EM4 $10 \%$ lebih efektif untuk menghasilkan biogas yaitu, tekanan gas total $104098 \mathrm{~N} / \mathrm{m}^{2}$, massa biogas $0,04286411 \mathrm{~kg}$, dan laju aliran massa biogas 0,0126653 kg/hari. Pada penambahan EM4 $9 \%$, untuk biogas yang dihasilkan yaitu, tekanan gas total $104000 \mathrm{~N} / \mathrm{m}^{2}$, massa biogas $0,04133325 \mathrm{~kg}$, dan laju aliran massa 0,0125884 $\mathrm{kg} /$ hari. Dan untuk perbandingan I dengan penambahan EM4 $8 \%$, untuk biogas yang dihasilkan yaitu, tekanan gas total $101984 \mathrm{~N} / \mathrm{m}^{2}$, massa biogas $0,0350515 \mathrm{~kg}$, dan laju aliran massa $0,125807 \mathrm{~kg} / \mathrm{hari}$.
\end{abstract}

Kata kunci : Biogas, Kotoran Sapi, EM4.

\section{Pendahuluan}

Energi biogas merupakan energi alternatif sebagai pengganti bahan bakar khususnya minyak tanah dan dipergunakan untuk memasak. Dalam skala besar, biogas dapat digunakan sebagai pembangkit energi listrik, karena biogas adalah energi yang dapat diperbarui (renewable).

Biogas ini diharapkan dapat mengurngai tergantungan terhadap bahan kabar fosil, dan dapat mendapatkan suatu profit untuk daerah pengembangan. Pada dasarnya segala macam bahan yang mengandung senyawa organik dapat dijadikan biogas, baik yang barasal dari sisa rumah tangga, sisa sayuran pasar atau yang berupa sampah ataupun kotoran hewan ternak seperti kotoran sapi. Kotoran hewan ternak khususnya kotoran sapi yang banyak di daerah pedesaan, selama ini hanya dimanfaatkan sebagai pupuk kandang untuk menyuburkan tanaman petani, dan meninggalkan bau yang tidak sedap bila terlalu banyak kotoran sapi yang menumpuk. Secara alami proses pembentukan biogas membutuhkan waktu yang relatif lama karena effective mikroorganisme yang berperan dalam proses fermentasi hanya berasal dari bahan organik yang membusuk.

Untuk meningkatkan efisiensi pembentukan kotoran sapi memerlukan optimalisasi peranan dari mikroorganisme. 
Hal ini dapat dilakukan dengan cara menambahkan aktivator EM4 (Effective mikroorganisme). [1]

EM4 (Effective microorganisme) yang dipakai untuk mempercepat degradasi merupakan inokulan dari jenis EM4. Inokulan mikroorganisme yang terdiri dari $90 \%$ Lactobacillus Sp ini memproduksi asam laktat yang dapat mempercepat perombakan bahan organik seperti lignin dan selulosa. [1]

\section{Landasan Teori}

\section{Biogas}

Biogas adalah gas yang dihasilkan dari proses penguraian bahan-bahan organik oleh mikroorganisme pada kondisi langka oksigen (anaerob). Komponen biogas: $\pm 60 \% \mathrm{CH} 4$ (metana), $\pm 38 \%$ $\mathrm{CO} 2$ (karbondioksida), $\pm 2 \% \mathrm{~N} 2, \mathrm{O} 2, \mathrm{H} 2$, dan H2S. Biogas dapat dibakar seperti elpiji, dalam skala besar biogas dapat digunakan sebagai pembangkit energi listrik, sehingga dapat dijadikan sumber energi alternatif yang ramah lingkungan dan terbarukan. [2]

Biogas yang didominasi oleh gas metana, merupakan gas yang dapat dibakar. Metana secara luas diproduksi dipermukaan bumi oleh bakteri pembusuk dengan cara menguraikan bahan organik. Bakteri metanogenesis berperan dalam pembusukan. Bakteri ini terdapat di rawarawa, lumpur sungai, sumber air panas (hot spring), dan perut hewan herbivora seperti sapi dan domba. Hewan-hewan ini tidak dapat memproses rumput yang mereka makan, bila tidak ada bakteri anaerobik yang memecah selulosa di dalam rumput menjadi molekul-molekul yang dapat diserap oleh perut mereka. Gas yang diproduksi oleh bakteri ini adalah gas metana. [2]
Tabel 1. Komposisi kandungan jenis gas [2]

\begin{tabular}{|l|c|}
\hline \multicolumn{1}{|c|}{ Jenis Gas } & Kandungan $(\%)$ \\
\hline Metana & $60-70$ \\
Karbondioksida & $30-40$ \\
Nitrogen & 3 \\
Hidrogen & $1-10$ \\
Oksigen & 3 \\
Hemiselulosa Sulfida & 5 \\
\hline
\end{tabular}

\section{Kotoran Sapi}

Kotoran sapi merupakan substrat yang dianggap paling cocok sebagai sumber pembuat gas bio, karena substrat tersebut telah mengandung bakteri penghasil gas metan yang terdapat dalam perut hewan ruminansia. Keberadaan bakteri di dalam usus besar ruminansia tersebut membantu proses fermentasi, sehingga proses pembentukan gas bio pada tangki pencerna dapat dilakukan lebih cepat. Walaupun demikian, bila kotoran tersebut akan langsung diproses dalam tangki pencerna, perlu dilakukan pembersihan terlebih dahulu.[2].

\section{Karakteristik Kotoran Sapi}

Tabel 2. Karakteristik Kotoran Sapi [3]

\begin{tabular}{|l|c|}
\hline \multicolumn{1}{|c|}{ Komponen } & Massa (\%) \\
\hline $\begin{array}{l}\text { Total padatan } \\
\text { Total padatan volatile } \\
\text { (mudah menguap) }\end{array}$ & $3-6$ \\
Total Kjeldahl & $80-90$ \\
Nitrogen & $2-4$ \\
Selulosa & $15-20$ \\
Lignin & $5-10$ \\
Hemiselulosa & $20-25$ \\
\hline
\end{tabular}

\section{EM4 (Efective Microoganisme)}

Merupakan suatu cairan berwarna kecoklatan dan beraroma manis asam (segar) yang di dalamnya berisi campuran beberapa mikroorganisme hidup yang menguntungkan bagi proses penyerapan/ persediaan unsur hara dalam tanah. Mikroorganisme atau kuman yang berwatak "baik" itu terdiri dari bakteri 
fotosintetik, bakteri asam laktat, ragi, aktinomydetes, dan jamur peragian. [5]

EM4 (Effective microorganisme) yang dipakai untuk mempercepat degradasi merupakan inokulan dari jenis EM4. Inokulan mikroorganisme yang terdiri dari $90 \%$ Lactobacillus Sp ini memproduksi asam laktat yang dapat mempercepat perombakan bahan organik seperti lignin dan selulosa. [1]

\section{Proses Pembentukan Biogas}

Pembentukan biogas dibagai menjadi tiga tahap yaitu :

a) Tahap Hidrolisis

pada tahap ini, bahan organik dienzimatik secara eksternal oleh enzim ekstraseluler (selulose, amilase, protase, dan lipase) mikroorganisme. Bakteri memutuskan rantai panjang karbohidrat kompleks, protein dan lipida menjadi senyawa rantai pendek. Sebagai contoh polisakarida diubah menjadi monosakarida sedangkan protein diubah menjadi peptida dan amino. [2]

b) Tahap Pengasaman (Asidifikasi)

Pada tahap ini bakteri menghasilkan asam, mengubah senyawa rantai pendek hasil proses pada tahap hidrolisis menjadi asam asetat, hidrogen (H2) dan karbondioksida. Bakteri tersebut merupakan bakteri anaerobik yang dapat tumbuh dan berkembang pada keadaan asam. Untuk menghasilkan asam asetat, bakteri tersebut memerlukan oksigen dan karbon yang diperoleh dari oksigen yang terlarut dalam larutan. Pembentukan asam pada kondisi anaerobik tersebut penting untuk pembentukan gas metana oleh mikroorganisme pada proses selanjutnya. Selain itu, bakteri tersebut juga mengubah senyawa yang bermolekul rendah menjadi alkohol, asam organik, asam amino, karbondioksida, $\mathrm{H} 2 \mathrm{~S}$ dan sedikit gas metana.

\section{Perhitungan Tekanan Gas}

Karena gas yang dihasilkan dalam proses digester relatif lebih kecil jadi dapat menggunakan manometer $\mathrm{U}$ dalam, perhitungan tekanan biogas tersebut dengan rumus sebagai berikut.

$P_{g}=P_{\text {udara }}+\rho \cdot g \cdot h$

Dengan :

$$
\begin{array}{ll}
P_{g} & =\text { Tekanan Biogas }\left(\mathrm{N} / \mathrm{m}^{2}\right) \\
P_{\text {udara }} & =\text { Tekanan udara luar }(\mathrm{atm}) \\
\rho & =\text { Masa Jenis } \mathrm{kg} / \mathrm{m}^{3} \\
\mathrm{~g} & =\text { Gravitasi } \\
\mathrm{h} & =\text { Perbedaan tinggi air }(\mathrm{m})
\end{array}
$$

\section{Perhitungan Massa Biogas}

Dalam mengetahui perhitungan massa biogas tersebut dapat digunakan rumus sebagai berikut :

$$
P V=m \cdot R \cdot T
$$

Sehingga :

$$
\mathrm{m}=\frac{P . V}{R \cdot T}
$$

Dengan :

$$
\begin{aligned}
\mathrm{P}= & \text { Tekanan gas }\left(\mathrm{N} / \mathrm{m}^{2}\right) \\
\mathrm{V}= & \text { Volume penyimpanan } \\
& \text { sementara }\left(\mathrm{m}^{3}\right) \\
\mathrm{m}= & \text { Massa gas }(\mathrm{kg}) \\
\mathrm{T}= & \text { Temperatur }\left({ }^{0} \mathrm{~K}\right) \\
\mathrm{R}= & \text { Konstanta, } 518 \mathrm{~N} \mathrm{~m} / \mathrm{kg}{ }^{0} \mathrm{~K}
\end{aligned}
$$

\section{Metode Penelitian}

Penelitian ini dilakukan di laboratorium teknik mesin UM Metro. Dalam penelitian ini menggunakan 3 variasi, dimana pada variasi yang dilakukan yaitu penambahan EM4 (Effective micrrorganisme) sebanyak 8\%, $9 \%$, dan $10 \%$. 


\section{Hasil dan Pembahasan}

Tabel 3. hasil Tekanan dan Massa Biogas pada penambahan EM4 8\%

\begin{tabular}{|c|c|c|c|c|}
\hline No & $\begin{array}{c}\text { Hari } \\
\text { ke }\end{array}$ & $\begin{array}{l}\text { Temp } \\
\left({ }^{0} \mathrm{C}\right)\end{array}$ & $\begin{array}{l}\text { Tekanan } \\
\mathrm{N} / \mathrm{m}^{2}\end{array}$ & Massa $(\mathrm{kg})$ \\
\hline 1 & 5 & 29 & 102087,2 & 0,061995 \\
\hline 2 & 10 & 29 & 102544,4 & 0,062232 \\
\hline 3 & 15 & 29 & 107063,9 & 0,065017 \\
\hline 4 & 20 & 29 & 103441 & 0,063232 \\
\hline 5 & 25 & 29 & 103985,5 & 0,062817 \\
\hline 6 & 30 & 29 & 102305 & 0,062127 \\
\hline \multicolumn{4}{|c|}{ Jumlah } & 0,37742 \\
\hline
\end{tabular}

Tabel 4. hasil Tekanan dan Massa Biogas pada penambahan EM4 9\%

\begin{tabular}{|c|c|c|c|c|}
\hline No & $\begin{array}{c}\text { Hari } \\
\text { ke }\end{array}$ & $\mid \begin{array}{c}\text { Temp } \\
\left({ }^{0} \mathrm{C}\right)\end{array}$ & $\begin{array}{l}\text { Tekanan } \\
N / m^{2}\end{array}$ & Massa ( kg ) \\
\hline 1 & 5 & 29 & 103689,2 & 0,062909 \\
\hline 2 & 10 & 29 & 103659,8 & 0,062968 \\
\hline 3 & 15 & 29 & 103875,6 & 0,063081 \\
\hline 4 & 20 & 29 & 104336,7 & 0,063361 \\
\hline 5 & 25 & 29 & 104238,6 & 0,063385 \\
\hline 6 & 30 & 29 & 102007,8 & 0,061947 \\
\hline \multicolumn{4}{|c|}{ Jumlah } & 0,377651 \\
\hline
\end{tabular}

Tabel 5. hasil Tekanan dan Massa Biogas pada penambahan EM4 10\%

\begin{tabular}{|c|c|c|c|c|}
\hline No & $\begin{array}{c}\text { Hari } \\
\text { ke }\end{array}$ & $\begin{array}{c}\text { Temp } \\
\left({ }^{0} \mathrm{C}\right)\end{array}$ & $\begin{array}{c}\text { Tekanan } \\
N / m^{2}\end{array}$ & Massa ( kg ) \\
\hline 1 & 5 & 29 & 103787,3 & 0,063028 \\
\hline 2 & 10 & 29 & 104042,4 & 0,063141 \\
\hline 3 & 15 & 29 & 104802,6 & 0,063644 \\
\hline 4 & 20 & 29 & 106210,4 & 0,064499 \\
\hline 5 & 25 & 29 & 104356,3 & 0,063456 \\
\hline 6 & 30 & 29 & 102406,1 & 0,062189 \\
\hline \multicolumn{4}{|c|}{ Jumlah } & 0,379957 \\
\hline
\end{tabular}

1. Pengaruh penambahan EM4 termperatur terhadap tekanan biogas yang dihasilkan.

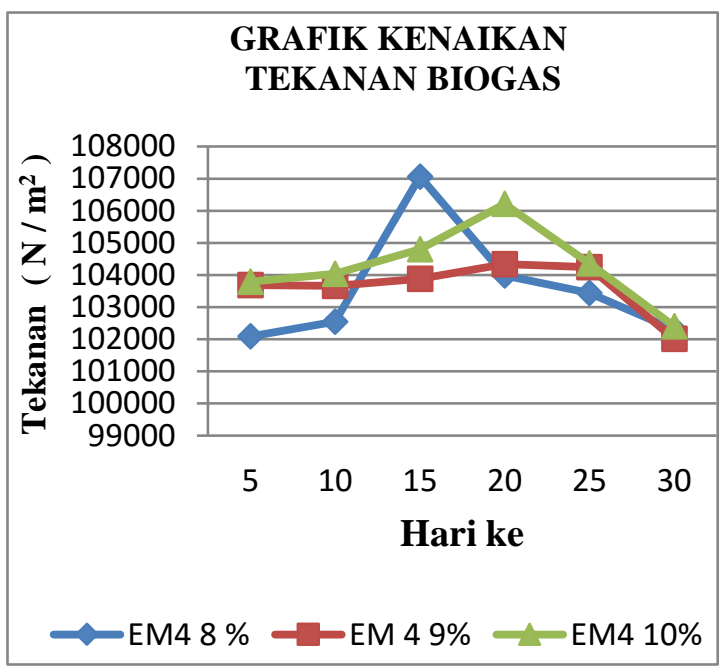

Gambar 1.Grafik Hubungan tekanan dan biogas.

Dari gambar 1 diatas dapat terlihat, bahwa pada penambahan EM4 8\% terdapat kenaikan tekanan yang cukup drastis yaitu pada harike lima belas, dan itu merupakan tekanan tertinggi dari pada variasi yang lain yaitu mencapai 107063,9 $\mathrm{N} / \mathrm{m}^{2}$ dengan suhu $29^{\circ} \mathrm{C}$. Pada penambahan EM4 $9 \%$, terlihat bahwa kenaikan tekanan yang ada tidak signifikan, tetapi terlihat stabil dan tekanan tertinggi pada hari ke 20 yang tekananya mencapai 104336,7 N/m². Pada penambahan EM4 $10 \%$, terlihat kenaikan tekanan cukup stabil dan tekanan biogas tertinggi pada hari ke 20 yaitu mencapai $106210,4 \mathrm{~N} / \mathrm{m}^{2}$. Jadi dari ketiga variasi penambahan EM4 untuk tekanan yang paling tinggi yaitu pada penambahan EM4 $8 \%$ pada hari ke 15 yaitu mencapai $107063,9 \mathrm{~N} / \mathrm{m}^{2}$. 
2. Pengaruh penambahan EM4 termperatur terhadap massa biogas yang dihasilkan

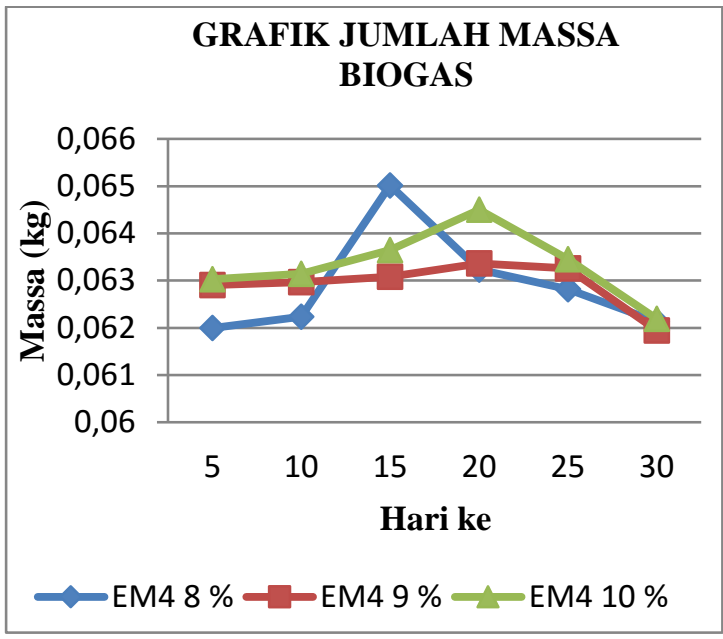

Gambar 2. Grafik Jumlah Massa Biogas

Dari gambar 2 diatas terlihat, dengan penambahan EM4 $8 \%$ siklus kenaikan jumlah biogas yang dihasilkan sama seperti kenaikan tekanan, karena dimana tekanan biogas naik jumlah biogas yang dihasilkan juga akan naik. Begitu juga sebaliknya apabila tekanannya turun hasilnya ikut turun. Hasil penelitian yang kami lakukan jumlah hasil biogas yang didapat yaitu, pada penambahan EM4 8\% adalah 0,37742 $\mathrm{kg}$, untuk penambahan EM4 9\% adalah $0,377651 \mathrm{~kg}$ dan untuk penambahan EM4 10\% yaitu 0,379957 kg. Pengaruh penambahan EM4 termperatur terhadap produksi biogas yang dihasilkan

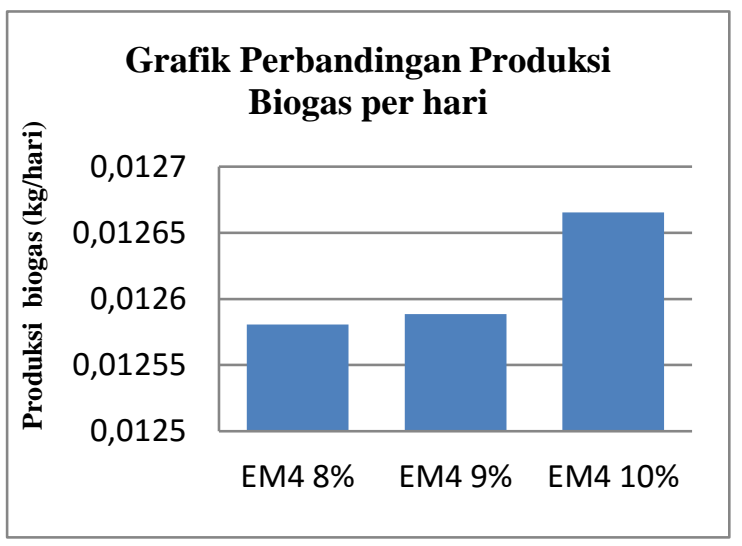

Gambar 3. Grafik Perbandingan Produksi Biogas per hari
Dari grafik diatas terlihat bahwa untuk produksi biogas perhari yang paling banyak adalah pada penambahan EM4 $10 \%$.

Dari ketiga variasi tersebut dapat disimpulkan bahwa untuk jumlah biogas yang didapat paling banyak pada penambahan EM4 10\%.

Jadi dari beberapa variasi yang dilakukan terlihat pengaruhnya dari penambahan EM4 sebagai starter, tetapi tekanan yang dihasilkan tidak berbanding lurus dengan hasil biogas untuk tekanan yang tertinggi pada penambahan EM4 8\% dan untuk hasil biogas yang paling banyak pada penambahan EM4 10\%.

\section{Kesimpulan}

Dari hasil penelitian yang telah dilakukan dapat disimpulkan sebagai berikut :

1. Pengaruh penambahan EM4 (Efective Mikroorganisme) terhadap hasil produksi biogas yang tertinggi yaitu pada penambahan EM4 10\% mencapai $0,379957 \mathrm{~kg}$.

2. Untuk tekanan biogas yang tertinggi pada penambahan EM4 $8 \%$ yaitu mencapai $107063,9 \mathrm{~N} / \mathrm{m}^{2}$.

3. Untuk produksi biogas yang paling banyak pada penambahan EM4 10\% yaitu $0,0125807 \mathrm{~kg} / \mathrm{hari}$.

\section{Daftar Pustaka}

[1] Sanjaya, I G M. 2010. “Biokonversi Sampah Organik Pasar Menjadi Biogas Menggunakan Stater Effektif Micro Organisme (EM4) “

[2] Lazuardy Indra, 2008 "Rancang Bangun Alat Penghasil Biogas Model Terapung " Fakultas Pertanian Universitas Sumatra Utara.

[3] Harahap Vesalina I. 2007 “Uji Beda Komposisi Campuran Kotoran Sapi Dengan Beberapa Jenis Limbah 
Pertanian Terhadap Biogas Yang Dihasilkan " Fakultas Pertanian Universitas Sumatra Utara.

[4] Ana Nurhasanah, dkk. 2009. "Perkembangan Digester Biogas Di Indonesia" Litbang deptan.

[5] Budiman, I gusti S., Kholisoh, Siti Diyar.,Marsetyo, Muhammad Muflikh., Putranti, Mira. 2010. Pengaruh Jenis Stater, Vulome Pelarut, dan Aditif terhadap Pengolahan Sampah Organik Rumah Tangga Menjadi Kompos Secara Aneroeb, Prosiding Seminar Nasional Teknik Kimia "Kejuangan" Pengembangan Teknologi Kimia untuk Penggolahan Sumber Daya Alam Manusia Indonesia, UPN Veteran yogyakarta. 